\title{
ON STOLARSKY AND RELATED MEANS
}

\author{
J. JAKŠETIĆ, J. PEČARIĆ AND ATIQ UR REHMAN
}

Abstract. We give a simple proof of the Stolarsky means inequality as well as some related inequalities for similar means of Stolarsky type.

Mathematics subject classification (2010): 26D10, 26D20, 26 D99.

Keywords and phrases: Convex function, log-convex function, Stolarsky means.

\section{REFERENCES}

[1] K. B. Stolarsky, Generalization of the logarithmic mean, Math. Mag., 48 (1975), 87-92.

[2] J. E. PeČarić, F. Proschan And Y. C. Tong, Convex functions, Partial Orderings and Statistical Applications, Academic Press, New York, 1992.

[3] J. E. PeČArić, I. PERIĆ AND H. M. SRivastava, A family of the Cauchy type mean-value theorems, J. Math. Anal. Appl., 306 (2005), 730-739. 